$1 \mathrm{~kg}$ of $20 \%$ protein-vitamin-mineral supplement for young pigs for fattening with a live weight of 70-110 kg contains not less than $12 \mathrm{MJ}$ of metabolisable energy, $900 \mathrm{~g}$ of dry matter, $350 \mathrm{~g}$ of crude protein, $28 \mathrm{~g}$ of lysine, $12 \mathrm{~g}$ of methionine + cystine, $5 \mathrm{~g}$ of tryptophan, not more than $50 \mathrm{~g}$ of crude fiber and $40 \mathrm{~g}$ of salt, not less than $39 \mathrm{~g}$ of calcium and $18 \mathrm{~g}$ of phosphorus.

It has been established that the use of complete feed for young pigs for fattening with a live weight of $70-110 \mathrm{~kg}$, according to the State Standard 4507:2005 leads to an increase in live weight of young pigs from 70 to $104 \mathrm{~kg}$ at the average daily gain - $756 \mathrm{~g}$ and at the conversion of $3.8 \mathrm{~kg}$ of mixed fodders per $1 \mathrm{~kg}$ of young pigs gain.

It was concluded that obtained productivity of young pigs using complete feed for young pigs for fattening with a live weight of 70-110 kg, according to the State Standard 4507:2005 has not met the requirements of intensive pig breeding and characterized by low economic efficiency of pork production.

It has been determined that the use of complete feed for young pigs for fattening with a live weight of 70-110 kg with low concentration of sodium chloride, calcium and phosphorus and improvement of pigs amino acid nutrition because of the threonine inclusion to the mixed fodder's composition must be the main direction to increase the productive qualities of young pigs. threonine.

Keywords: pigs feeding complete feed, feed conversion, buffer capacity, sodium chloride, calcium, phosphorus,

1. Kombikormy povnoratsionni dlia svynei. Tekhnichni umovy: DSTU 4124-2002 [Chynnyi vid 2004-01-01]. - K.: Derzhspozhyvstandart Ukrainy, 2003. - 13 s.

2. Kombikormy dlya kontrolnoyi vidgodivli svynei. Texnichni umovy: DSTU 4507:2005 [Chynnyi vid 2007-04-01]. - K.: Derzhspozhyvstandart Ukrainy, 2007. - 11 s.

3. Riznychuk I. F. Produktyvni yakosti molodniaku svynei u vitsi vid 91 do 130 dib za vykorystannia povnoratsionnoho kombikormu /I. F. Riznychuk// Zernovi produkty i kombikormy. - 2016. - № 3 (63). - S. 21-25.

4. Durst L. Kormlenie selskohozyaystvennyih zhivotnyih / L. Durst, M. Vittman / pod red. I. I. Ibatullina, G. V. Provatorova. Vinnitsa: Nova Kniga, 2003. - 384 s.

5. Futterberechnung für Schweine. - Bayerische Landesanstalt für Tierzucht , 1996. - № 10. - P. 7.

6. Futterberechnung für Schweine. - Freising: Institut für Tierernährung und Futterwirtschaft, 2004. - № 14. - P. 9.

7. Ferkelfütterung. Aktuelle Versuche Versuchsergebnisse 2004. - Freising: Institut für Tierernährung und Futterwirtschaft, 2004. $-50 \mathrm{p}$.

Надійшла 07.11.2016. До друку 28.11.2016

\title{
ЕНЕРГЕТИЧНИЙ АУДИТ ТЕХНОЛОГІЇ ПЕРЕРОБКИ ВОЛОГИХ КОРМОВИХ ТРАВ
}

\begin{abstract}
Анотація
Серед багатьох технологічних прочесів, щзо застосовують як у харчовій промисловості, так $і$ кормовиробництві, одним із найпоширеніших є енергоємний процес сушіння. Загальний потенціал енергоефективності при сушінні кормових трав, який визначається різницею між фактичними та теоретичними витратами палива на випаровування 1 кг води, коливається у діапазоні 0,86 - 1,3 МДж/кг. В сучасних умовах зростаючого дефіциту комбікормової сировини та енергетичної кризи не втрачає актуальності пошук шляхів зниження витрат на паливно-енергетичні ресурси шляхом реалізації інновачійних технологій екструдування вологих кормових засобів у суміші з іншими компонентами комбікорму.

Мета роботи полягає у визначенні внутрішнього потенціалу енергоефективності у комбікормовому виробництві при використанні у якості сировини вологих кормових засобів без їх попереднього або наступного сушіння на прикладі кормової трави лючерни. Об'єктом дослідження є технологічний процес переробки вологих кормових трав у складі комбікормів. Визначено, щуо в базовій, так і традиџійній технології найбільш енергоємним є прочес ектрудування, оскільки він споживає енергію у кількості 500 МДж/m, за новою - $423 \mathrm{MДж/m.} \mathrm{При} \mathrm{чому} \mathrm{у} \mathrm{новій} \mathrm{технології} \mathrm{на} \mathrm{цеей} \mathrm{проиес} \mathrm{припадає} 57 \%$ від загальних витрат на електрику, а у базовій - $49 \%$, щүо пояснюється додатковим навантаженням на екструдер - зневодненням. На випаровування 1 кг води при екструдуванні витрачається енергія 2,94 МДж/кг, шо максимально наближсається до теоретичного значення 2,7 МДж/ кг. Таким чином потенціал енергоефективності (0,24 МДж/m) у изьому випадку мінімізований.

Проведений енергетичний аудит базової (традиційної) та нової технологї виробництва комбікормової продукиії з включенням кормових трав довів, щчо в результаті застосування прочесу екструдування з метою зневоднення нова технологія є енергоефективною у порівнянні з традиційною технологією сушіння кормових трав та подальшого виробництва продукиії з включенням трав'яної муки, а значить і економічно дочільною, оскільки відбувається загальна економія паливноенергетичних ресурсів 714 МДж/m (47\%).
\end{abstract}

Ключові слова: енергоефективність, електроенергія, паливо, паливно-енергетичні ресурси, екструдування, комбікорм, трав'яна мука 
Вступ

Постійне зростання цін на електрику, паливо, газ змушує населення та виробників вдаватися до енергоощадних заходів. Адже відомо, що витрати на реалізацію цих заходів у $2-3$ рази менші, ніж на видобуток енергоресурсів чи їх закупівлю [1-3]. Більш актуальним представляється розробка та впровадження енергоефективних технологій, які б зменшували їх загальну енергоємність без зниження обсягів виробництва продукції у всіх галузях агропромислового комплексу України, зокрема у кормовиробництвi $[4,5]$

Серед багатьох технологічних процесів, що застосовують як у харчовій промисловості, так і кормовиробництві, одним із найпоширеніших $\epsilon$ енергоємний процес сушіння - термічний процес видалення вологи 3 матеріалу шляхом ії випаровування. Сушіння $\epsilon$ універсальним способом зневоднення продукції рослинництва, вторинних сировинних ресурсів 3 метою їх консервування. Так отримують трав'яну, рибну, м'ясну, кров'яну, кісткову, м'ясо-кісткову муку, сухий буряковий жом, тощо.

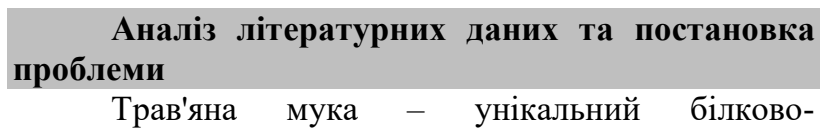
вітамінний кормовий засіб, роль якого в годівлі тварин важко переоцінити. Її промислове виробництво в світі започаткували ще на початку 50 -х років минулого сторіччя 3 метою виготовлення поживного кормового засобу з мінімальними втратами поживних та біологічно активних речовин, який виступав би альтернативою сіну чи сінажу [6].

У 2010 році індустрія виробництва трав'яної муки 3 люцерни, наприклад, в Європі включала 300 заводів та 50 фермерських господарств, які виготовляли 4200 млн.т продукції [7]. Але в Україні внаслідок своєї високої енергоємності виробництво трав'яної муки майже припинилось.

Нині промислове виробництво трав'яної муки має сталу технологію, основні етапи та режими якої майже не відрізняються у всьому світі. Традиційний спосіб отримання гранульованої трав'яної муки передбачає скошування бобових трав із вологістю понад $70 \%$ у стадії бутонізації (злакових - в стадії виходу в трубку) 3 одночасним подрібненням, завантаженням цієї маси у транспортні засоби, які постачають їі до сушарного агрегату, високотемпературне сушіння до кінцевої вологості 9 - 12 \%, подрібнення, гранулювання та охолодження [8 - 12].

Питомі витрати електроенергії у промисловому виробництві гранульованої трав'яної муки складають в середньому 177 кВт год/т або 636 МДж/т (при початковій вологості кормових трав 70 \%) [13 15]. При чому аналіз структури витрат електроенергії показує, що більша іiі частка 66 \% припадає саме на процес сушіння [16]. При сушінні у якості джерела енергії використовується не тільки електрика, а й паливо. Паливо-енергетичний баланс цієї технології (табл. 1) показує, що дизельне паливо забезпечує біля 92,3 \% всіх потреб обладнання в енергії, а його вартість складає 92,7 \% від загальних витрат на всі паливно-енергетичні ресурси (ПЕР). На електрику ж при- падає лише 7,7 \% від загальних потреб, а витрати на iii оплату становлять також 7,3 \% від загальних витрат на придбання ПЕР. Тобто 3 паливо-енергетичного балансу технології виробництва гранульованої трав'яної муки слідує, що найдорожчим джерелом енергії, яке використовується в процесі сушіння, є паливо, а сама технологія сушіння кормових трав $\epsilon$ вкрай енерговитратою.

Для високотемпературного сушіння вологих кормових засобів застосовують, як правило, пневмобарабанні сушарки типу АВМ з конвективним підводом теплоти $[8,17]$. Процес відбувається наступним чином. Енергоносій подається спеціальним устаткуванням в камеру згоряння. Отримані топкові гази разом із повітрям при температурі $600-1000{ }^{\circ} \mathrm{C}$ всмоктуються в сушарний барабан. У цей же барабан за допомогою транспортеру подається, наприклад, подрібнена зелена маса. Разом із потоком теплоносія, який нагнітається вентилятором, зелена маса потрапляє в барабан сушарки і просувається через його циліндри до виходу. 3 сушарки висушена маса попадає до циклону, в якому відбувається іiі відокремлення від теплоносія [8].

У якості енергоносія у пневмобарабанних сушарках типу АВМ використовують дизельне паливо через відсутність газифікації більшості підприємств. Теплова ж енергія, отримана 3 нього, є одним із найдорожчих джерел енергії. При сушінні спостерігається 3 етапи конверсії енергії палива: паливо $\rightarrow$ газ $\rightarrow$ сушарний агент $\rightarrow$ продукт. I на кожному 3 цих етапів відбуваються незворотні втрати енергії (рис. 1). Енергія палива 1 у топці 2 перетворюється в енергію паливних газів. При чому через неповноту згоряння втрачається $\mathrm{Q}_{1}$ енергії. Енергія газів в змішувачі 3 шляхом перемішування з повітрям трансформується в енергію агента сушіння з втратами енергії $\mathrm{Q}_{2}$. Агент сушіння транспортується до барабану сушарки із втратами $\mathrm{Q}_{3}$ через його випромінювання при транспортуванні, продувку через газохід, тощо. Безпосередньо в барабані сушарки 4 агент сушіння віддає свою енергію продукту з втратами $\mathrm{Q}_{4}$ через корпус сушарки, з відпрацьованим теплоносієм та продуктом.

Саме вказані втрати енергії зумовлюють високі витрати палива та низьку ефективність використання енергоносіїв, малий ККД сушарки.

Відомо, що для перетворення води в пару під час сушіння твердого тіла, необхідно витратити енергію порядку 2,7 МДж/кг [8, 18, 19]. Фактичні ж витрати енергії палива при сушінні коливаються у великому діапазоні. Так, наприклад, для виробництва 1 т трав'яної муки стандартної вологості у пневмобарабанних сушарках типу АВМ при висушуванні трави люцерни:

- 3 початковою вологістю 82 \% (підлягає випаровуванню 4100 кг води) фактично витрачається 390 л дизельного палива,

- 3 початковою вологістю 75 \% (підлягає випаровуванню 2600 кг води) фактично витрачається 220 л дизельного палива, що еквівалентно 9266 МДж енергії,

- 3 початковою вологістю 70 \% (підлягає випаровуванню 2000 кг води) фактично витрачається 


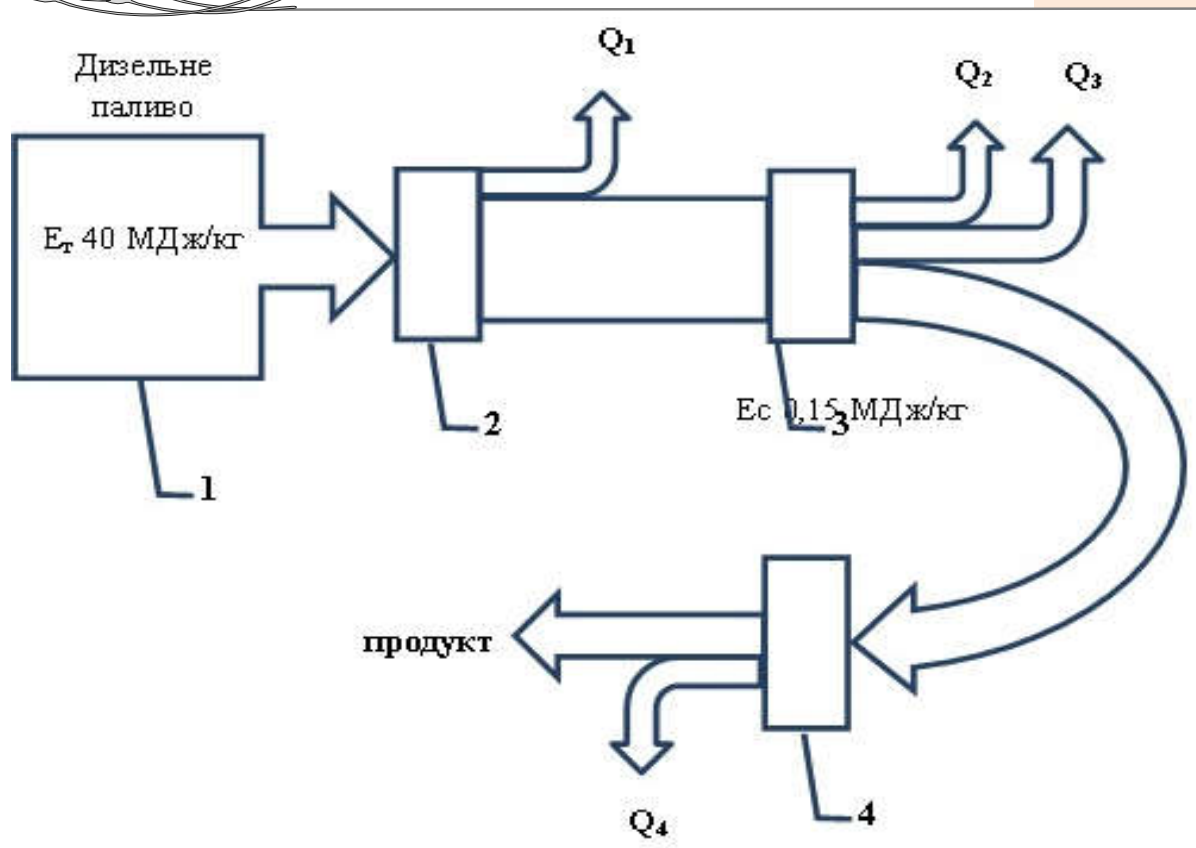

пропоновано та науково обгрунтовано нову інноваційну технологію виробництва комбікормової продукції з використанням вологих кормових засобів без їх попереднього або наступного сушіння, який розкриває резерви ресурсів сировинної бази комбікормового виробництва, у тому числі за рахунок кормових трав та зеленої маси культурних рослин [20]. В цій технології провідне місце належить процесу екструдування, задача якого окрім підвищення кормової цінності та знезараження, полягає ще й у зневодненні.

Рис. 1 - Конверсія енергії дизельного палива в пневмобарабанній сущарці

Об'скт, мета та задачі дослідження

Об'єктом дослідження є технологічний процес переробки вологих кормових трав у складі комбікормів.

Мета роботи полягає у визначенні внутріш-

180 л дизельного палива.

Загальний потенціал енергоефективності при сушінні, який визначається різницею між фактичними та теоретичними витратами палива на випаровування 1 кг води, коливається у діапазоні 0,86 - 1,3 МДж/кг (табл. 1). Відомо, що чим більше значення потенціалу енергоефективності, тим більше резерв ii підвищення. Можливі два принципово різних шляхи підвищення резервів: енергозбереження та впровадження енергоефективних технологій. Загальні ознаки енергозбереження - нормовані витрати енергії, регламентація іiі витрат та відключення при дефіциті 3 метою мінімізації витрат. Заходи по енергозбереженню при сушінні зазвичай спрямовані на економію палива за рахунок оптимізації режимів сушіння, зменшення втрат теплоти у навколишне середовище, тощо. Загальні ознаки енергоефективності технології - зменшення загальної енергоємності процесів без зниження обсягів виробництва продукції, екологічна безпечність виробництва та продукції в цілому. Більш перспективною $є$ розробка енергофективних технологій.

Припустимо наступну гіпотезу: технологія переробки вологих кормових засобів, у тому числі трав'яної різки, може бути енергоефективною за умов заміни енергії, що отримується 3 палива, електричною енергією або уникнення процесу сушіння взагалі.

В Одеській національній академії харчових технологій на кафедрі технології комбікормів і біопалива під керівництвом д.т.н., проф. Сгорова Б.В. занього потенціалу енергоефективності у комбікормовому виробництві при використанні у якості сировини вологих кормових засобів без їх попереднього або наступного сушіння на прикладі кормової трави люцерни.

Для досягнення поставленої мети вирішені наступні задачі:

- проведено підбір та розрахунок необхідного технологічного обладнання для принципової технологічної схеми виробництва комбікормової продукції 3 включенням вологих кормових трав;

- проведено енергетичний аудит базової (традиційної) та нової технології виробництва комбікормової продукції з включенням кормових трав.

\section{Матеріали та методи дослідження}

Визначення потенціалу енергоефективності здійснювали шляхом порівняльного енергетичного аудиту запропонованої та базової технологій. Він полягає у розрахунку кількості спожитої енергії, енергетичному балансі і порівнянні отриманих величин при дослідженні існуючої традиційної технології виробництва трав'яної муки, базової та нової технологій виробництва комбікормової продукції.

Виходячи $з$ принципової технологічної схеми виробництва комбікормової продукції, проводили підбір та розрахунок необхідного технологічного обладнання згідно з методиками, наведеними у [21].

Таблиця 1 - Резерви енергоефективності процесу сушіня кормових трав у барабанних агрегатах

\begin{tabular}{|c|c|c|c|c|}
\hline \multirow{2}{*}{$\begin{array}{c}\text { Початкова } \\
\text { вологість люцерни, } \\
\%\end{array}$} & \multicolumn{2}{|c|}{$\begin{array}{c}\text { Питомі витрати енергії палива на } \\
\text { сушіння, МДж/т }\end{array}$} & \multirow{2}{*}{$\begin{array}{c}\text { Фактичні витрати па- } \\
\text { лива на випаровування } \\
1 \text { кг води, МДж }\end{array}$} & \multirow{2}{*}{$\begin{array}{c}\text { Резерв енергое- } \\
\text { фек-тивності, } \\
\text { МДж/кг }\end{array}$} \\
\hline & етеоретичні & феактичні & & \\
\hline 82 & 11070 & 16429 & 4 & 1,3 \\
\hline 75 & 7020 & 9266 & $3,3,56$ & 0,86 \\
\hline 70 & 54500 & $7 \overline{7582}$ & 3,79 & 1,09 \\
\hline
\end{tabular}


На комбікормових підприємствах облік енергоспоживання здійснюється шляхом фіксації кількості отриманих енергоносіїв. Тому при проведенні енергоаудиту базової та незмінної ділянки вдосконаленої технологій використовували паспортні дані устаткування, а у випадку нової технології на ділянках, що піддаються змінам, - данні експериментальних досліджень [22, 23].

Експериментальне виготовлення зразків партій розсипного та екструдованого комбікормуконцентрату розробленого складу [14] із включенням різки синьогібридної люцерни у кількості 20 \%, пров'яленої до вологості $70 \%$, проводили у відповідності із рекомендаціями "Правил організації і ведення технологічного процесу виробництва продукції комбікормової промисловості” [24].

Технологічний процес екструзії дослідних зразків комбікорму проводили в ОНАХТ на кафедрі Технології комбікормів і біопалива в екструдері марки E3-150 (Bronto). Продуктивності екструдера визначали шляхом зважування маси, що вийшла з вихідного отвору гвинтової частини екструдера протягом 20 хв. Отриманий результат, перемножений на 3 , характеризує годинну продуктивність установки. Для приведення продуктивності до умовної щільності 750 кг/м ${ }^{3}$ отриману величину продуктивності множили на коефіцієнт, який визначається розділенням умовної щільності, на фактичну. Продуктивність установки визначали за умови, що навантаження струму основного електродвигуна складає $100 \%$, якість екструдованого продукту задовільна, а температура відповідає заданій. До початку роботи здійснювали підключення до екструдеру амперметра та ватметра для визначення енергосилових характеристик. Після запуску прес виводили на режим, при якому його продуктивність, температура процесу та завантаження по струму електродвигуна повинні відповідати номінальним значенням.

Потужність, що споживалась електродвигуном екструдера, визначали із періодичністю 2 - 5 хв. шляхом вимірювання напруги в мережі, спожитого струму та коефіцієнту потужності. Вимірювання цих величин здійснювали за допомогою вольтметру, амперметру та фазометру відповідно. Потужність розраховували за формулою:

$$
N=U \cdot I \cdot \cos \varphi,
$$

де $U$ - напруга мережі, В;

$I-$ спожитий струм мережі, А;

$\cos \varphi-$ коефіцієнт потужності.

Сумарну встановлену потужність розраховували, як добуток потужності електродвигуна технологічного обладнання на його кількість. Подібний розрахунок проводили за кожною 3 технологічних ліній та його результати використовували для розрахунку питомих витрат електроенергії у енергетичному та кошторисному виразі за кожною 3 технологічних ліній. Питомі витрати електроенергії у енергетичному виразі визначали за формулою:

$$
N_{\text {num }}=\frac{\sum N}{Q} \text {, }
$$

де $\Sigma N$ - сумарна спожита потужність електродвигунів устаткування, що виконує дану операцію, етап, та ін., кВт;

кг/год.

$Q$ - продуктивність устаткування (лінії),

Питомі витрати електроенергії у кошторисному виразі розраховували шляхом множення питомих витрат електроенергії у енергетичному виразі на промисловий тариф на електроенергію. Далі розраховували сумарні витрати електроенергії за всією технологією (базовою та новою) при фактичній вологості. Для коректного порівняння та аналізу отриманих величин перераховували їх на суху речовину.

\section{Результати дослідження}

Нову технологію рекомендовано реалізовувати на комбікормових підприємствах невеликої потужності через близькість сировини. Вона повинна бути спроможною переробляти кормові трави в обсязі, не меншому ніж базова технологія виробництва трав'яної муки. Мінімальна продуктивність сушарного агрегату типу АВМ складає 0,65 т/год по трав'яній муці (2,7 т/год по сировині). Для проектування схеми технологічного процесу, підбору та розрахунку необхідного технологічного обладнання базової та нової технологій виробництва комбікормової продукції приймаємо продуктивність 18 т/год. Для реалізації цих технологій згідно 3 розробленою рецептурою передбачено лінії, наведені в табл. 2 [16, 25, 26].

Для розрахунку технологічного обладнання для кожної з ліній приймали наступні витрати сировини: зернова $60 \%$, шроти $15 \%$, борошниста - $20 \%$, кормові трави $15 \%$, мінеральна сировина $4 \%$, премікс - $1 \%$, гранульована трав'яна мука $-5 \%$. Кінцеві результати розрахунку необхідного технологічного обладнання наведено у табл. 2 .

На підставі отриманих даних визначаємо питомі витрати електроенергії у енергетичному та кошторисному виразі (табл. 3).

Таким чином, економія електроенергії при реалізації нової технології при обраному варіанті технологічної схеми у порівнянні з базовою складають 84,6 кВт·год/т (125,2 грн/ т) сухої речовини. Однак у базовій технології виробництво трав'яної муки відбувається шляхом високотемпературного сушіння, при якому використовується дизельне паливо. Тому для коректного порівняння питомих енерговитрат базової та нової технологій проведено комплексний технікоекономічний аналіз усіх витрат ПЕР (табл. 4).

У відповідності до висунутої гіпотези, звичайний ланцюг виробництва (рис. 2) буде зазнавати наступних змін (рис. 3). Скошені кормові трави піддають попередній різці, пров'ялюванню та транспортують до сушарного агрегату, сполученого із обладнанням для подальшого гранулювання. Виготовлену гранульовану трав'яну муку упаковують в мішки та транспортують до комбікормового заводу, де в свою чергу за традиційною технологію виробляють комбікорм із певним вмістом трав'яної муки. Загальні питомі витрати електроенергії будуть становити 1015 МДж/т ( 1186 МДж/т на суху речовину). 
Таблиця 2 - Розрахунок енергосмності технологічного обладнання

\begin{tabular}{|c|c|c|c|c|c|}
\hline \multirow{3}{*}{ Назва лінії } & \multirow{3}{*}{$\begin{array}{c}\text { Продуктив- } \\
\text { ність лінї̈, } \\
\text { т/год }\end{array}$} & \multicolumn{4}{|c|}{ Сумарна встановлена потужність за технологією } \\
\hline & & \multicolumn{2}{|c|}{ базовою } & \multicolumn{2}{|c|}{ Новою } \\
\hline & & кВТ & МДж & кВТ & МДж \\
\hline Лінія підготовки зернової сировини & 10,0 & 151,4 & 545 & 151,4 & 545 \\
\hline Лінія екструдування зернової сировини & 10,0 & 1603 & 5760,5 & - & - \\
\hline Лінія підготовки шротів & 2,7 & 57,2 & 205,9 & 57,2 & 205,9 \\
\hline Лінія борошнистої сировини & 3,6 & 2,2 & 7,9 & 2,2 & 7,9 \\
\hline Лінія підготовки мінеральної сировини & 0,7 & 23,5 & 84,6 & 23,5 & 84,6 \\
\hline Лінія гранульованої трав'яної муки & 0,9 & 24,2 & 87,1 & - & - \\
\hline Лінія трав'яної різки & 2,7 & - & - & 26,1 & 94 \\
\hline Лінія передсумішей сипких компонентів & 15,3 & - & - & 23,5 & 84,6 \\
\hline 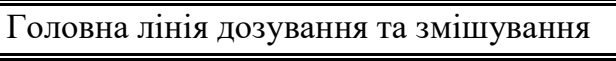 & 18,0 & 23,5 & 84,6 & 10 & 36 \\
\hline Лінія гранулювання комбікорму & 18,0 & 437,3 & 1574,3 & - & - \\
\hline "Лінія екструдування комбікорму & 18,0 & - & 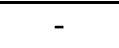 & 2193,7 & 7897,3 \\
\hline
\end{tabular}

Таблиця 3 - Енергетичний аудит

\begin{tabular}{|c|c|c|c|c|c|c|}
\hline \multirow{4}{*}{ Назва лінії } & \multicolumn{6}{|c|}{ Питомі витрати електроенергії на технологію у виразі } \\
\hline & \multicolumn{4}{|c|}{ енергетичному } & \multicolumn{2}{|c|}{ кошторисному, грн/т } \\
\hline & \multicolumn{2}{|c|}{ базову } & \multicolumn{2}{|c|}{ нову } & \multirow{2}{*}{ базову } & \multirow{2}{*}{ Нову } \\
\hline & кВт·год/т & МДж/т & кВт·год/т & МДж/т & & \\
\hline Лінія підготовки зернової сировини & 15,1 & 54,5 & 15,1 & 54,5 & 22,4 & 22,4 \\
\hline Лінія екструдування зернової сировини & 160,2 & 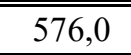 & - & - & 237,3 & - \\
\hline Лінія підготовки шротів & 21,2 & 76,3 & 21,2 & 76,3 & 31,4 & 31,4 \\
\hline Лінія борошнистої сировини & 0,6 & 2,2 & 0,6 & 2,2 & 0,9 & 0,9 \\
\hline Лінія підготовки мінеральної сировини & 32,6 & 117,5 & 32,6 & 117,5 & 48,3 & 48,3 \\
\hline Лінія гранульованої трав'яної муки & 26,9 & 96,8 & - & - & 39,8 & - \\
\hline Лінія трав'яної різки & - & 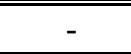 & 9,7 & 34,8 & - & 14,3 \\
\hline Лінія передсумішей сипких компонентів & - & - & 1,5 & 5,5 & - & 2,3 \\
\hline Головна лінія дозування та змішування & 1,3 & 4,7 & 0,6 & 2 & 1,9 & 0,8 \\
\hline Лінія гранулювання комбікорму & 29,3 & 87,5 & - & - & 36 & - \\
\hline Лінія екструдування комбікорму & - & - & 121,9 & 4438,7 & - & 180,4 \\
\hline $\begin{array}{l}\text { Усього на технологію: } \\
\text { при фактичній вологості } \\
\text { у перерахунку на суху речовину }\end{array}$ & $\begin{array}{l}282,4 \\
320,9 \\
\end{array}$ & $\begin{array}{l}1015,4 \\
1153,9 \\
\end{array}$ & $\begin{array}{l}203,2 \\
236,3\end{array}$ & $\begin{array}{l}731,5 \\
850,6\end{array}$ & $\begin{array}{c}418 \\
474,9\end{array}$ & $\begin{array}{l}300,8 \\
349,7\end{array}$ \\
\hline
\end{tabular}

Таблиця 4 - Техніко-економічний аналіз витрат ПЕР, на 1 m сухої речовини

\begin{tabular}{|c|c|c|c|c|c|}
\hline \multirow{3}{*}{ Технологія виробництва } & \multicolumn{5}{|c|}{ Витрати на паливо-енергетичні ресурси у виразі } \\
\hline & \multicolumn{2}{|c|}{ енергетичному, МДж } & \multicolumn{3}{|c|}{ кошторисному, грн. } \\
\hline & $\begin{array}{c}\text { електро- } \\
\text { енергії }\end{array}$ & $\begin{array}{c}\text { дизельного } \\
\text { палива }\end{array}$ & $\begin{array}{c}\text { електро- } \\
\text { енергії }\end{array}$ & $\begin{array}{c}\text { дизельного } \\
\text { палива }\end{array}$ & Сумарні \\
\hline Трав’яної муки & 636 & 7582 & 262 & 3330 & 3592 \\
\hline Комбікормів-концентратів & 1154 & - & 475 & - & 475 \\
\hline Усього (комбікорм з 5 \% трав’яної муки) & 1186 & 379 & 488 & 167 & 655 \\
\hline Екструдованих комбікормів-концентратів (нова) & 851 & - & 350 & - & 350 \\
\hline
\end{tabular}

* Тариф на електроенергію для підприємств складає 148,02 коп/кВтгод, за 1 л рідкого палива - 18,50

грн. (ціни квітень 2015 р.) 


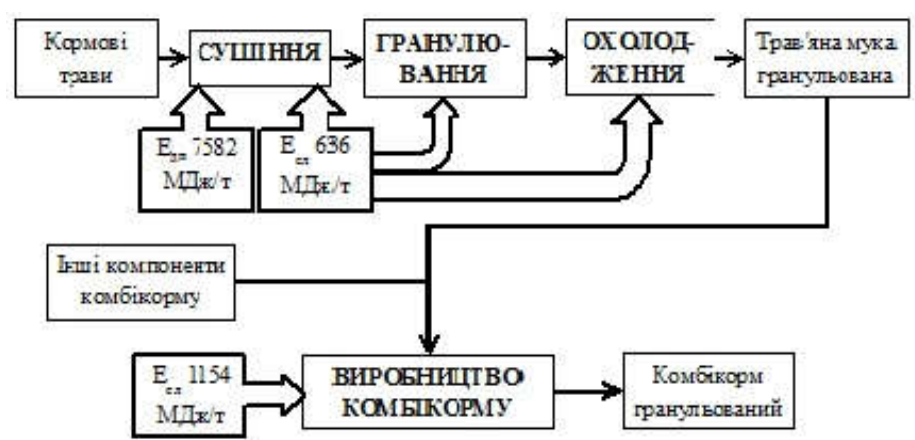

Рис. 2 - Система традиційної технології виробництва гранульованої трав'яної муки та комбікорму

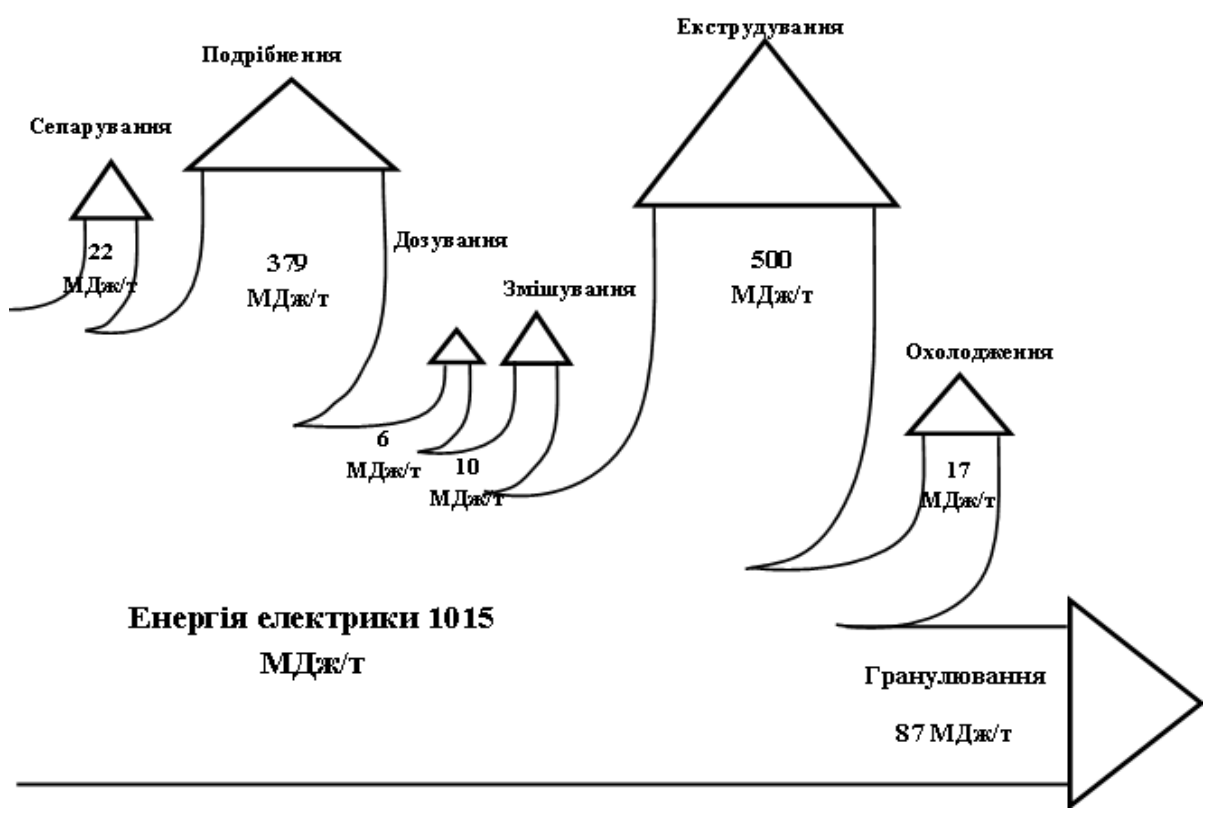

Рис. 4 - Потоки електричної енергї̈ при виробництві комбікормової продукції за базовою технологісю, розподілені на технологічні процеси

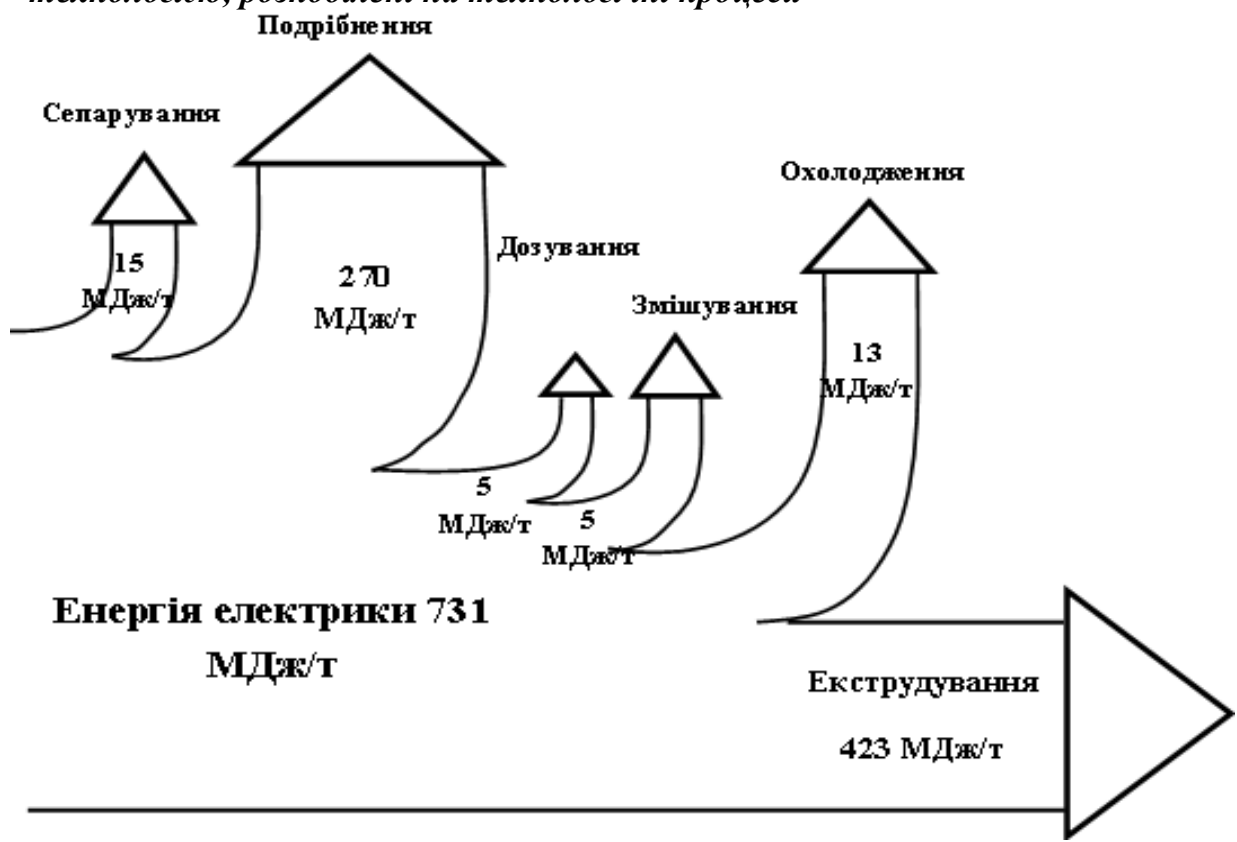

Рис. 5 - Потоки електричної енерхї̈ при виробництві комбікормової продукції за новою технологією, розподілені на технологічні процеси

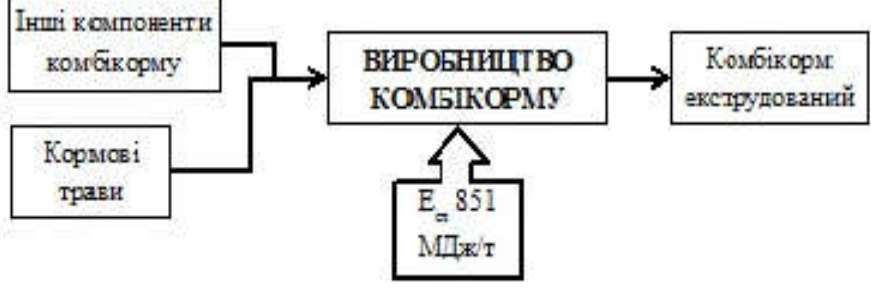

Рис. 3 - Система нової технологї виробництва екструдованого комбікорму

Нова технологія передбачає суттєве скорочення технологічних операцій, зменшення транспортних витрат. Кормові трави готують аналогічно, як для сушіння та транспортують, але не до сушарного агрегату, а на комбікормовий завод. Там на першому етапі готують порцію (попередню суміш) очищеної та здрібненої сировини, накопичують у наддозаторних бункерах. До складу передсуміші входять всі сипкі компоненти, передбачені рецептурою комбікорму. Сировину, що не увійшла до складу попередньої суміші, - підв'ялені кормові трави очищають, здрібнюють та накопичують у наддозаторному бункері. На головній лінії дозують та змішують підготовлені компоненти разом з попередньою сумішшю сипких компонентів, екструдують, та охолоджують. Загальні питомі витрати електроенергії будуть становити 732 МДж/т ( 851 МДж/т на суху речовину).

При чому потоки електричної енергії в кожній 3 систем при виробництві комбікормів розподіляються наступним чином (рис. 4, 5).

\section{Обговорення результатів}

Як в новій, так і традиційній технологіях найбільш енергоємним є процес ектрудування, оскільки за базовою технологією він споживає енергію у кількості 500 МДж/т, за новою 423 МДж/т. При чому у новій технології на цей процес припадає 57 \% від загальних витрат на електрику, а у базовій - 49 \%. В новій технології це пояснюється 
додатковим навантаженням на екструдер - зневодненням.

Однак через це вважати запропоновану технологію енерговитратною помилково. На випаровування 1 кг води в новій технології витрачається енергії 2,94 МДж/кг, що максимально наближається до теоретичного значення 2,7 МДж/ кг. Таким чином потенціал енергоефективності (0,24 МДж/т) у цьому випадку є мінімальним з розглянутих.

Техніко-економічний аналіз витрат ПЕР показав, що виключення енергоємного процесу сушіння навіть при використанні наденергоємного екструдування дозволяє суттєво зменшити витрати на ПЕР. Економія палива складає 9 л/т (379 МДж/т), а електроенергії - 335 МДж/т (у виразі на суху речовину комбікорму) або у кошторисному виразі - 167 грн/т та 138 грн/т відповідно.

Серед сильних сторін можна зазначити доведену енергоефективність нової технології переробки вологих кормових трав у складі комбікормової продукції, розширенні сировинної бази комбікормового виробництва. Нова технологія передбачає суттєве скорочення технологічних операцій, зменшення транспортних витрат.

Слабі сторони нової технології полягають у тому, що визначена іiі енергоефективність не є константою, оскільки може змінюватися в залежності від особливості побудови технологічного процесу на конкретному підприємстві, встановленому обладнані, тощо.

Перспективними є більш глибокі дослідження процесу екструдування вологих кормових трав по визначенню внутрішнього потенціалу енергоефективності в залежності від початкової вологості сировини, та ін. Нова технологія $є$ екологічно безпечною, оскільки повністю відмовляється від використання дизельного палива, тобто уникає викидів вуглекислого газу у навколишнє середовище. Отримана комбікормова продукція вільна від канцерогенів, тобто іiі згодовування дозволить отримати безпечну для людини тваринницьку продукцію.

Складності при впровадженні нової технології полягають у постійно зростаючих цінах на електроенергію, відсутності вітчизняних прес-екструдерів великої продуктивності. Останне звужує коло запровадження нової технології до комбікормових заводів невеликої продуктивності.

\section{Висновки}

Таким чином проведений енергетичний аудит базової (традиційної) та нової технології виробництва комбікормової продукції з включенням кормових трав довів, що в результаті застосування процесу екструдування 3 метою зневоднення нова технологія постає енергоефективною у порівнянні з традиційною технологією сушіння кормових трав та подальшого виробництва продукції з включенням трав'яної муки, а значить і економічно доцільною, оскільки відбувається загальна економія ПЕР 714 МДж/т, тобто 47 \%. Запропонований спосіб зневоднення вологих кормів та розроблена на його підставі технологія виробництва комбікормової продукції є дійсно енергоефективною і може у подальшому розглядатися як альтернатива процесу сушіння.

\section{ЛІТЕРАТУРА}

1. Бевз, В.В. Енергоефективність підприємств харчової промисловості - сучасний стан $і$ стратегія розвитку [Текст] / В. В. Бевз // Наукові праці Наџіонального університету харчових технологій. - 2010. - T. 1. - №. 35 - С. $15-17$.

2. Бевз, В. В. Енергозбереження - ефективний илях до зниження витрат виробництва [Текст] / В. В. Бевз // Харчова промисловість. - 2010. - № 9. - С. 190-194.

3. Бевз, В. В. Зниження енергоємності продукиії - інновачійний шлях розвитку підприсмств харчової промисловості [Текст] / В. В. Бевз // Фінанси, облік, аудит: зб. наук. праць. - К.: КНЕУ. - 2011. - № 17. - С. 16-24.

4. Мацевитый, Ю.М. Перспективы энерго- и ресурсосбережения на основе интеграчионной модели развития территориально-промышленных комплексов [Текст] / Ю.М. Мачевитый, В.В. Соловей, А.И. Васильев // Технологический аудит и резервы производства. - 2014. - № 6/1 (20). - С. $26-31$.

5. Скорук О. П. Перспективи розвитку відновлювальної енергетики в Україні [Текст]/ О. П. Скорук //Економіка АПК. - 2013. - №. 5. - С. 63-67. Скорук, О. П. (2013). Перспективи розвитку відновлювальної енергетики в Украӥні. Економіка АПК, (5), 63-67

6. Кайнов, А. Комплексная линия по производству травяной муки [Текст] / А. Кайнов// Комбикорма. - 2012. - № 4. C. 41-42.

7. Guillemot, E. The European alfalfa drying system Режим доступy http://alfalfa.ucdavis.edu/+symposium/2011/files/talks/11WAS-3_Guillemont_EuropeanSystems.pdf

8. Зафрен, С. Я. Технология приготовления кормов [Текст]/ С. $\bar{Я}$. Зафрен //M.: Колос. - 1977. - 239 c.

9. Sokhansanj, S. Kinetics of dehydration of green alfalfa [Text] / S. Sokhansanj, R. T. Patil //Drying technology. - 1996. - T. 14. - №. 5. - C. 1197-1234.

10. Wood, H.C. Heat treatment of chopped alfalfa in rotary drum dryers [Text]/ H.C. Wood, S. Sokhansanj // Journal: Drying Technology. - Volume 8, Issue 3, January 1990. - P. 543-569.

11. Patil, R. T. Thin layer drying of components of fresh alfalfa [Text] / R. T. Patil and all// Canadian Agricultural Engineering. - 1992. - T. 34. - C. 343-343.

12. Wu, H. Alfalfa drying properties and technologies-in review [Text] / H. Wu //Nature and Science. - 2004. - T. 2. - № 4. C. 65-67.

13. Mujumdar A. S. (ed.). Handbook of industrial drying. - Crc Press, 2014.

14. Adapa P. K. et al. Customized and value-added high quality Alfalfa products: A new concept //Agricultural Engineering International: CIGR Journal. - 2007. Adapa, P. K., Schoenau, G. J., Tabil, L. G., Arinze, E. A., Singh, A. K., \& Dalai, A. K. (2007). Customized and value-added high quality Alfalfa products: A new concept. Agricultural Engineering International: CIGR Journal 
15. Кучинскас, 3.М. Оборудования для сушки, гранулирования и брикетирования кормов [Текст] / 3.М. Кучинскас, В.И. Особов, Ю.Л. Фругер. - М.: Агропромиздат, 1988. - 208 с.

16. Егоров, Б. В.Экструдирование при переработке комбикормов повышенной влажности [Текст] / Б. В. Егоров, О. Г. Бурдо, В. В. Гончаренко, Н. В. Хоренжий // Хранение и переработка зерна. - 2005. - № 9. - С.33 - 37.

17. Muller C. J. C. et al. The drying rate and chemical composition of field and artificially dried lucerne hay //South African Journal of Animal Science. - 2008. - T. 38. - №. 4. - C. 350-354.

18. Бурдо, О.Г. Энергетический мониторинг пищевых производств [Текст] / О.Г.Бурдо - Одесса: Полиграф, 2008. $244 c$.

19. Mujumdar A. S. Superheated Steam Drying //Handbook of industrial drying. - 2014. - C. 421

20. Хоренжий, Н.В. Оцінка продуктивної дї комбікормової продукції із включенням вологих кормових трав у годівлі великої рогатої худоби [Текст] // Наук. праці / ОНАХТ. - О., 2014. - Вип. 46. T. 1. - С. 70 - 76.

21. Єгоров, Б. В. Методичні вказівки до виконання курсового та дипломного проектування для студентів професійних напрямів підготовки 7.05170101, 8.05170101 денної та заочної форм навчання. У 3-х ч. [Текст] / Сгоров Б.В., Кочетова А.О., Макаров О.П., Браженко В.С., Пулатов В.Б. - Одеса, ОНАХТ, 2011.

22. Будро, О.Г. Методические указания к изучению курса «Основы энергетичекого менеджмента» [Текст] / О.Г.Бурдо. - Одесса, ОНАПТ, 2003 г. -40 c.

23. Праховник, А.В. Энергетический менеджмент [Текст] / А.В. Праховник, А.И. Соловей, В.В. Прокопенко и др. - К.: IЕЕНТУУ «КПИ», 2001. - $472 \mathrm{c}$.

24. Правилах організації і ведення технологічного процесу виробництва комбікормової продукцї̈ [Текст]. - К.: Міністерство агропромислового комплексу Украӥни, Київський інститут хлібопродуктів, 1998. - 220 с.

25. Егоров, Б.В. Экструдированные комбикорма на основе лючерновой резки [Текст] / Б.В. Егоров, В.В. Гончаренко, Н.В. Хоренжий // Зернові продукти і комбікорми. - 2004. - № 3. - С. 30 - 34

26. Сгоров, Б.В. Технологічні основи пориійної технології виробництвва комбікормів для великої рогатої худоби [Текст]/ Б.В. Сгоров, Н.В. Хоренжий// 3б. доп. міжнар. конф. “Україна. Комбікорми -2004” -Київ, 2004. -С. 70-72.

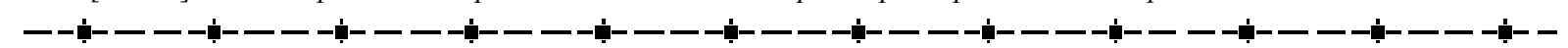

\section{O.G. BURDO, DSc, Professor, Head of the processes, equipment and energy management, N.V. KHORENZHY, PhD., Associate professor, Candidate of technical science Odessa National Academy of Food Technologies, Ukraine \\ ENERGY AUDIT OF TECHNOLOGY FOR THE WET FORAGE GRASSES PROCESSING}

\footnotetext{
Abstract

Among the many processes that are used as food industry and fodder production, one of the most common is energy-intensive drying process. The total potential energy when drying forage grasses, defined by the difference between the actual and theoretical fuel consumption for evaporation of $1 \mathrm{~kg}$ of water varies in the range of $0.86-1.3$ $\mathrm{MJ} / \mathrm{kg}$. In modern conditions of growing shortage of animal feed raw materials and energy crisis urgent even finding ways to reduce the cost of fuel and energy resources by implementing innovative technologies moist feed extrusion facilities in mixtures with other components of feed. Purpose is to determine the internal potential energy in fodder production using as raw wet feed facilities without their prior or subsequent drying by the example of fodder grass alfalfa. Object is a technological processing of wet forage grasses in the composition of animal feed. Determined that in the basic and traditional technology is the most energy intensive process ektruduvannya because it consumes energy of $500 \mathrm{~mJ} / \mathrm{m}$, the new - $423 \mathrm{MJ} / \mathrm{t}$. What does the new technology to process $57 \%$ of the total cost of electricity, and the base - 49\%, due to additional load on the extruder - dehydration. On evaporation of $1 \mathrm{~kg}$ of water during extrusion energy consumed $2.94 \mathrm{MJ} / \mathrm{kg}$, which is close to the maximum theoretical value of $2.7 \mathrm{MJ} / \mathrm{kg}$. Thus potential energy $(0.24 \mathrm{MJ} / \mathrm{t})$ in this case is minimized. The conducted energy audits of base (conventional) and new technologies of production of animal feed products with the inclusion of forage grasses showed that as a result of the process of extruding the purpose of dewatering new technology is energy efficient compared with the conventional technology of drying forage grasses and subsequent production of grass meal inclusion and hence economically feasible, as is the overall economy of energy resources $714 \mathrm{MJ} / \mathrm{t}(47 \%)$.

\section{REFERENCES}

1. Bevz, V. (2010). Energy efficiency of the food industry - the current state and development strategy. Proceedings of the National University of Food Technologies, 35 (1), 15 - 17.

2. Bevz, V. (2010). Energy conservation - an effective way to reduce production costs. Food industry, 9, 190-194.

3. Bevz, V. (2011). Reducing the energy intensity of production - an innovative way of development of the food industry. Finance, accounting, auditing, collection of scientific papers, 17, 16-24.

4. Matsevityi, Yu. (2014). Prospects for energy-and resource-based integration model of development of territoriallyindustrial complexes. Technology audit and production reserves, № 6/1 (20), $26-31$.

5. Skoruk, O. (2013). Prospects for renewable energy in Ukraine. The Economy of Agro-Industrial Complex, 5, $63-67$

6. Kainov, A. (2012). Complete line for the production of grass meal. Compound feeds, 4, 41-42.

7. Guillemot, E. The European alfalfa drying system Режим доступy http://alfalfa.ucdavis.edu/+symposium/2011/files/talks/11WAS-3_Guillemont_EuropeanSystems.pdf

8. Zafren, S. (1977). Feed preparation technology, Moskow, Kolos, 239.

9. Sokhansanj, S., \& Patil, R. T. (1996). Kinetics of dehydration of green alfalfa. Drying technology, 14(5), 1197-1234.

10. Wood, H. C., \& Sokhansanj, S. (1990). Heat treatment of chopped alfalfa in rotary drum dryers. Drying technology, 8(3), 543-569.
} 
11. Patil, R. T., Sokhansanj, S., Arinze, E. A., \& Schoenau, G. (1992). Thin layer drying of components of fresh alfalfa. Canadian Agricultural Engineering, 34, 343-343.

12. $W u, H$. (2004). Alfalfa drying properties and technologies-in review. Nature and Science, 2(4), 65-67

13. Mujumdar, A. S. (Ed.). (2014). Handbook of industrial drying. Crc Press

14. Adapa, P. K., Schoenau, G. J., Tabil, L. G., Arinze, E. A., Singh, A. K., \& Dalai, A. K. (2007). Customized and value-added high quality Alfalfa products: A new concept. Agricultural Engineering International: CIGR Journal

15. Kuchynskas, Z., Osobov, V., \& Freher, Yu.. (1988). The equipment for drying, granulation and briquetting feed. Moskow, Ahropromyzdat, ${ }^{208 .}$

16. Yehorov, B., Burdo, O., Goncharenko, V., \&, Khorenzhyy, N. (2005) Extrusion in the processing of high humidity mixed fodders. Storage and processing of grain, 9, $33-37$.

17. Muller, C. J. C., Cruywagen, C. W., Du Toit, F. J., \& Botha, J. A. (2008). The drying rate and chemical composition of field and artificially dried lucerne hay. South African Journal of Animal Science, 38(4), 350-354

18. Burdo, O. (2008) Energy monitoring of food manufactures. Odessa, Polyhraf, 244.

19. Mujumdar, A. S. (2014). Superheated Steam Drying. Handbook of industrial drying, 421

20. Khorenzhyy, N. (2015). Assessment of productive action animal feed products with the inclusion of moist forage grasses in feeding cattle. Researsh works ONAFT, 1 (46), 70 - 76.

21. Yehorov, B., Kochetova, A., Makarov, O., Brazhenko, V., \& Pulatov, V. (2011) Guidance for course and diploma projects for students of professional training areas 7.05170101, 8.05170101 full-time and distance learning. Odessa, ONAFT.

22. Burdo, O. (2003) Methodical specified for the Study course "Fundamentals of power machinery Management". Odessa, ONAFT, 40.

23. Prakhovnyk, A., Solovei, A., \& Prokopenko V. Energy management, Kyiv: IEENTUU «KPY», 472.

24. Rules of organization and management of the process of production of animal feed products (1998). K .: The Ministry of agriculture of Ukraine, Kyiv Institute of bread, 220.

25. Yehorov B., Goncharenko, V., \&, Khorenzhyy, N. (2004) Extruded fodder based on alfalfa cutting. Grain products and mixed fodders, 3, $30-34$.

26. Yehorov, B., Goncharenko, V., \&, Khorenzhyy, N. (2004) Technological fundamentals of batch production technology of fodder for cattle. Zb. dop. mizhnar. konf. "Ukraine. Compouned feeds - 2004”, Kyiv, 70- 72.

Надійшла 13.09.2016. До друку 22.09.2016

\title{
LABOUR PROTECTION AND INDUSTRIAL SAFETY IN UKRAINE; PROBLEMS OF TRANSITION PERIOD AND PERSPECTIVE WAYS OF DEVELOPMENT
}

\begin{abstract}
Based on comparative analysis of the industrial accident causes in Ukraine and EU countries this article establishes that the main accident reasons are organizational ones (50 to $70 \%$ of the total number of cases), however such indicators as the registered in Ukraine fatal cases frequency coefficient (per 1 thousand of employees) and the fatal accidents-total accidents number ratio are greater than the similar indicators in Europe by about 2- and 100-fold, respectively.

It is noted that the issues of improving the work safety in Ukraine towards the association with the European Union should be considered in the context of two main planes, which are associated with changes in the legislative and educational systems.

Within this article, the authors analyse the main inter-sectoral and sectoral regulatory legal acts on labour protection, in particular in the field of providing for fire, explosion and electrical safety, and relevant documents relating to the creation and maintenance of a comfortable environment at work.

Based on the conducted analysis, the problems of adapting the national legislation in the field of labour protection and industrial safety to the legal framework of EU, the problems concerning the unsystematic character and selective approach to the implementation of appropriate changes, and potential hazards that can occur at all stages of the life cycle of technical systems in the event of their introduction are determined.

The main differences in the systematic approach to the professional training of students in higher educational institutions (HEI) of Ukraine and EU countries (Poland, for example) in the field of labour protection and industrial safety are singled out. It is noted that in the Republic of Poland numbering the population correlative with Ukraine the quantity of special educational institutions preparing specialists in the field of labour protection in relation to the total number of higher educational establishment is 1.9 fold greater than the corresponding figure in Ukraine, and the number of subjects with regard to the issues of the labour protection and industrial safety, which are taught to students in fulfilling the work programmes at nonspecialised Polish higher educational establishments is greater than that in Ukrainian several fold.

The statistical data regarding the dynamics of the accident number increase in Ukraine and their causes within a period of 2015 and 2016 are presented and analysed in the context of recent negative changes including the reduction of class hours for stu-
\end{abstract}

(C) “Зернові продукти і комбікорми”, 2016 